\title{
Objektiewe Skrifuitleg? \\ Kanttekeninge by Skrifuitleg \\ in die Ned Geref Kerk 1930-1990
}

\author{
F E Deist \\ Universiteit van Suid-Afrika
}

\begin{abstract}
Objective interpretation of Scripture? Marginal notes to the interpretation of Scripture in the Dutch Reformed Church 1930-1990
\end{abstract}

This article seeks to understand developments in biblical scholarship in the Dutch Reformed Church in the period 1930 to 1990 from the perspective of epistemology and methodology, and that of socio-political history. It also tries to explain developments on the epistemological level from the perspective of socio-political history. An explanation is thus attempted for the sometimes confusing fact that apartheid, which was once presented as a 'biblical' imperative by the Dutch Reformed Church has recently, on 'biblical' grounds, been proclaimed a sin by the same church.

Daar word teenswoordig nog in teologiese kringe melding gemaak van 'objektiewe' Skrifuitleg (vgl Potgieter 1989:28-36). Intussen het dieselfde 'objektiewe' Skrifuitleg teoloë wat apartheid eers as Skriftuurlik gefundeerd beskou het, daartoe gebring om dit as 'n sonde te beskou. Iets wat eens op Bybelse gronde vir die wil van God aangesien is, word vandag, eweneens op Bybelse gronde, as kettery beskou.

Wat het gebeur? Dit is die vraag waarop hierdie artikel 'n antwoord probeer verstrek. In die proses sal die vraagstelling egter wyer uitwaaier na die verband tussen sosio-politieke omstandighede, kenteorie en Skrifverklaring.

- Die artikel is 'n verwerking van 'n referaat wat op 13 Augustus 1990 op uitnodiging van die OosKaapse werkgemeenskap van die S A Akademie vir Wetenskap en Kuns aan die Universiteit van Port Elizabeth gchou is. 
Die artikel lê besondere klem op die gesprek in die Ned Geref Kerk. Die 'uitsondering' van dié kerk wil nie voorgee dat teoloë in ander (Afrikaanse) kerke tussen 1930 en 1990 stilgesit het nie. Die redes vir die fokus is drieërlei. In die eerste plek is die keuse bloot pragmaties. Dit gaan in dié artikel oor ' $n$ illustrasie van die invloed van nie-teologiese aangeleenthede op teologiese argumentasie in die algemeen en Skrifuitleg in die besonder. Tydens 'n omvattende RGN-ondersoek na 'Wetenskapsteorie en vakmetodologie in die Bybelwetenskappe in Suid-Afrika' was ek verantwoordelik vir die navorsing oor die Ned Geref Kerk, sodat die materiaal oor dié kerk vir my die gerieflikste beskikbaar was. Tweedens is die radikale teenoorstaande bevindings van Skrifondersoek seker op min ander plekke so duidelik as in die gesprek in die Ned Geref Kerk. Derdens sentreer die verklaring wat vir dié omwenteling aangebied word rondom die aanvanklike aanvaarding en latere verwerping van 'Boerecalvinisme', 'n denkrigting wat nie noodwendig die ontwikkelinge in byvoorbeeld die Nederduitsch Hervormde Kerk van Afrika kan verklaar nie, aangesien teoloë in dié kerk teenstanders van Neo-Calvinisme was.

\section{DIE ERA VAN AFRIKAANSE SEKERHEDE}

Ná die Eerste en Tweede Wêreldoorloë het die negentiende-eeuse liberale optimisme in Europa begin smoor, het die idealistiese evolusieskemas van Darwin en Hegel begin steier onder die kritiek van nihilistiese eksistensialisme, en het teologiese sekerhede onder die druk van die na-oorlogse swaarkry gekom. Hegel se idealistiese rykmansideologieë het plek begin maak vir Marx se materialistiese armmansideologieë en nasionalistiese drome vir anargistiese utopias, terwyl teologiese sekerhede plek begin maak het vir die God-is-dood-teologie. Negentiende-eeuse uitroeptekens is vervang met twintigste-eeuse vraagtekens en die eén wêreld van vroeër het verskeur geraak in 'n eerste, 'n tweede en 'n derde wêreld.

Dié filosofiese en teologiese vraagtekens is sedert die twintigerjare saam met studente se oorsese bagasie in Suid-Afrika uitgepak en is deur die pos uit Europa by ons afgelewer. Afrikaners was egter maar nog aan die orentsteier uit die onsekerhede wat hulle ná die Tweede Vryheidsoorlog, die groot griep en die twee depressies, die groot trek na die stede en die armblankedom geteister het. Onsekerheid was daarom die laaste ding wat tóe hier welkom was. Lategan (1944:13) skryf byna angsbevange in dié verband: 'Ook ons beleef moeilike, gevaar- en kommervolle tye ...deur die gevaarlike stroom van die Humanisme...En die Humanisme word gesteun deur die magtige handlangers van die Rasionalisme, die Naturalisme, die Materialisme, die Baalisme, die Ateïsme, die Totalitarisme, die Kommunisme' (klem toegevoeg). 
Die Ned Geref Kerk het elke (ingevoerde) onsekerheid met alles tot sy beskikking probeer bestry. En so het die era van onsekerheid in Europa by ons die era van die groot sekerheid ingelui. Die hele verhaal is te lank om hier weer te gee (vir meer besonderhede oor die sosio-politieke omstandighede, kyk Deist 1990). 'n Paar kursoriese opmerkings en aanhalings uit geskrifte van die dertiger- en veertigerjare sal illustreer waaroor dit gaan.

Die Ned Geref Kerk het hom, soos dit die kerk van Christus betaam, aan die kant van die Afrikaners geskaar in hulle stryd om menswaardigheid en hom tot die Bybel gewend vir 'n woord vir die tyd. Hó dit alles gebeur het, is egter 'n verhaal waaroor 'n mens soms verbysterd staan, want in die proses het teoloë 'n paar diep teue uit bronne náás die Bybel getrek wat die Bybel self 'n heel spesifieke karakter en funksie gegee het.

\section{DIE ON'ISTAAN VAN 'N BOERE-CALVINISME}

Alreeds in 1934 bemerk Die Kerkbode (1934-12-12) 'n groeiende beweging' in die land ten gunste van 'n 'herfundering van ons volkslewe op Kalvinistiese grondslag en die samevatting van alle organisasies wat enigsins werk in die rigting van die reoriëntering van ons volkslewe volgens die Christelik-Nasionale beginsels van ons volksverlede....' Dit was juis hierdie 'Calvinisme' wat mettertyd die sleutel sou word waarmee die Bybel in die Ned Geref Kerk uitgelê sou word. Daarom moet dié Calvinisme van nader bekyk word.

Die 'Calvinisme' waarvan hier sprake is, het op twee bene gestaan wat op hulle beurt op dieselfde kenteorie gebaseer was. Aan die een kant was daar die Kuyperse kultuurfilosofie en aan die ander kant 'n fundamentalistiese Skrifbeskouing, wat reeds sedert die middel van die tweede dekade van die eeu 'n vastrapplek in die Ned Geref Kerk gekry het (Deist 1986:36-50).

Die historiese omstandighede waarbinne Kuyper sy kultuurfilosofie uitgewerk het, het hom ' $n$ afkeer gegee in die ideale van die Franse Rewolusie, sodat sy filosofie 'n sterk outoritêre kleur, en sy kultuurmodel 'n anti-demokratiese kleur gekry het, en voorts volks-, eerder as nasionaal, georiënteerd was.

Vir Kuyper was daar, soos trouens ook volgens die Nederlandse Geloofsbelydenis, twee kenbronne vir die wil van God, naamlik die natuur en die Skrif, wat nooit met mekaar in konflik kon wees nie. Wat van God in die natuur bekendgemaak is, moes klop met hoe Hy Hom in die Skrif geopenbaar het. Dié interpretasie van 'natuur' en 'Skriftuur' as kenbronne van die openbaring het aan die 'natuurlike' (in soverre dit Skriftuurlik onderbou kon word) 'n normatiewe karakter gegee. Om die wil van God te ken, moes 'n mens dus die natuur skerp waarneem en die Bybel reg interpreteer. Wanneer 'n (objektiewe) waarneming in die natuur inderdaad met 'n 
(objektiewe) uitleg van die Skrif gekorreleer het, was daar geen 'maar' op die bevinding te sê nie. Dan het daardie bevinding die status van 'n ewige en onveranderlike goddelike beginsel verkry.

Op voetspoor van dié denkmodel het Afrikaners uit hulle alledaagse ervaring waarnemings gemaak oor wat sosio-polities 'natuurlik' is, en dié waarnemings dan Skriftuurlik onderbou. Die gereedskap wat hulle tot hulle beskikking gehad het vir die Skrifoefening, was 'n mengsel van Amerikaanse fundamentalisme en Kuyperse fondasionalisme (vgl Van Heerden 1988:147-180).

Vir die fundamentalisme was die Bybel die letterlike, en daarom feillose en gesagvolle Woord van God. Geen historiese, volkekundige, natuurkundige of geografiese detail daarin kon foutief wees nie. So skryf Kotze ([1933]:183-197): '[D]ie Heilige Gees...het die ganse Skrif met die skeppings- en sondevalverhaal, met geskiedenis, kronologie, outeurskappe, geslagsregisters, ens ens onfeilbaar geïnspireer ...Ons hele teologie, ons godsdiens, ons saligheid rus op die inspirasie van die Bybel.'

As 'n mens byvoorbeeld by jouself 'n natuurlike afkeer in 'rasvermenging' vind en jy sien dat Israel telkens letterlik in die Bybel verbied word om met die ander nasies te meng, bevestig die Skrif die natuur en word apartheid 'n ewige goddelike volkekundige beginsel.

Hierdie skynbaar dwingende argument berus egter op die naïef-realistiese kenteorie van die Scottish Common Sense Realism waarop sowel die Kuyperse kultuurfilosofie as die fundamentalistiese Skrifbeskouing gebaseer was, en wat Thomas Reid ontwerp het om elke vorm van (Berkerleyaanse) skeptisisme oor menslike kennis te ontsenu. Volgens dié teorie sien 'n mens ' $n$ ding presies soos dit in sigself is, en is alle geredekawelry oor perspektiwiteit en relatiwiteit van kennis blote filosofiese tydverdryf.

Mettertyd het naïewe realisme, fund amentalisme en Kuyperianisme by ons vervleg geraak om 'n beskouing tot stand te bring wat onder Afrikaners as 'Calvinisme' bekend gestaan het, maar wat nòg Kuyperianisme nòg fundamentalisme nòg 'common sense' pragmatisme was. Wat hier ontstaan het, was 'n derde verskynsel en Afrikaners van die tyd was besonder trots op dié ontwikkeling. Erasmus (1946) wys byvoorbeeld met genoegdoening daarop dat daar in Suid-Afrika "n eie Afrikaanse Calvinisme' ontstaan het wat nie 'n 'ingevoerde Calvinistiese stempel wil dra nie, nie 'n anderlandse Calvinistiese tipe na-aap nie, nie die spreekbuis van oorsese Calviniste [wil] wees nie,' maar wat 'ons eie Boerepad loop'. Dis 'n Calvinisme wat hom aangepas het by die 'nasionale verskille van aanleg, temperament, volksaard, geskiedenis en omstandighede' en wat 'ons volk in die vorige eeu bewaar [het], aan die een kant teen verengelsing en aan die ander kant teen verbastering'. 
Die teologiese onderbou van hierdie Boere-Calvinisme het, op voetspoor van Kuyper, wel 'gereformeerd' geheet, maar was eweneens 'n Afrikaanse weergawe van gereformeerdheid. Groenewald (1952:509) beskryf dit as "n teologie wat uit eie bodem en volksverlede spruit en beter as enige vreemde die geestelike voedsel vir die volk van hierdi[e] bodem kan voorberei en aanbied'.

Hierdie Boere-Calvinisme het teoloë die sekerhede gebied wat hulle gesoek het en het die sleutel geword waarmee die Bybel ontsluit is. Omdat die sisteem so logies gesluit het, het die grense tussen Skrif, belydenis, en Boere-Calvinisme vervaag en is enigeen wat van Boere-Calvinistiese oortuigings verskil het, nie slegs as antiAfrikaans beskou nie, maar ook gesien as iemand wat die Skrif en die belydenis van die kerk geloën het. Daarom kon Lategan (1941:306) sê: 'Volgens ons Kerkleer spreek ons van 'n ware en 'n valse Kerk en is ons, as Gereformeerdes oortuig, dat die Calvinistiese standpunt van die Gereformeerde Kerke die suiwerste openbaring bevat van die goddelike waarheid...' en noem Vorster (1936:186) die Calvinistiese leer 'die skoonste uitdrukking...van die Evangelie van onse Heiland en Meester' - 'n teologie wat 'onder Hoër Hand die Kruisevangelie teen Roomse goeie werkeleer en Modernistiese en Metodistiese selfverlossingsleer verdedig en gehandhaaf het'.

Op voetspoor van hierdie 'Boereteologie' kon Die Kerkbode (Redaksioneel 1948:392) sê: 'Wat ons vandag nodig het, is die aanwakkering van die ware gereformeerde vroomheid onder ons volk...wat in ooreenstemming is met die Skrif en belydenis en met die Calvinistiese karakter van ons volk' (klem toegevoeg).

Selfs 'gereformeerde vroomheid' is dus mettertyd met Boere-Calvinisme ofte wel Christelik-Nasionale beskouings geïdentifiseer en as die enigste ware interpretasie van die Skrif en belydenis beskou.

Die selfversekerde identifikasie tussen Skrif, belydenis en Calvinisme verklaar waarom die frase contra principia negantem, non est disputandum (met diegene wat van die Calvinistiese uitgangspunt verskil, kan daar nie geargumenteer word nie [Kock 1936:85]) so dikwels in die geskrifte van die tyd voorkom, en waarom die rubriek ('Uit die Vrystaat' 1948:62) met soveel oortuiging kon sê: 'Daar moet...vir die Kerk van Christus 'n Kerkleer wees langs die Bybel...As iemand nou nie dié leer bring nie, moet lidmate hul onskriftuurlike liefde en verdraagsaamheid laat staan....'

Dit was maar enkelinge wat, soos Moller (1934:1241), gewaarsku het: 'Die "Afrikaanse" Kalvinisme...het op 'n Afrikaanse perd geklim wat hulle op die Afrikaanse bodem met Afrikaanse grond baie ongenadig sal laat kennis maak.'

\section{DIE WIL VAN GOD VIR DIE BOEREVOLK}

Boere-Calvinisme het dit vir die Ned Geref Kerk moontlik gemaak om Afrikaners se natuurlike voor- en afkeure as Skriftuurlik verantwoord te legitimeer en daarmee 
as Godsopenbaring te sanksioneer. Dis waarom Strauss (1947:7) met betrekking tot rasseverhoudings kon sê: 'Laat ons die sif van ons natuurlike afkeer dig maak met die sement van die Calvinisme? (klem toegevoeg). Dit is presies wat die Ned Geref Kerk gedoen het. Loots (1957:527) skryf (klem toegevoeg): 'Ons apartheidsbeleid op kerklike en staatkundige gebied...is 'n lewwensbeginsel wat die groot Skepper volgens die Skrif en die Natuur ingestel het, en hierdie beginsel moet die Afrikanervolk en die Boerekerk handhaaf tot die uiterste toe, ook en veral [teen die] gelykstellingsbeleid van die moderne liberalisme.'

Apartheid was dus nou 'n skeppingsordening wat uit die natuur afgelees en deur die Skrif bevestig is. Daarom kon Potgieter (1958) sê: 'Dit sou regdraads indruis teen die geopenbaarde wil van God om vermenging van Blankes, Kleurlinge en Bantoes te bepleit. Soos Kuyper hom teen die eenvormigheidsideaal van die Franse Revolusie verset het, is ons vandag geroepe om die kreet wat die Liberaliste as geesteskinders van hierdie Revolusie aanhef, te bestry - teenoor hulle eiedunklike gelykheid moet gestel word die Skriftuurlike veelvormigheid.'

\section{DIE OMMEKEER}

Dat daar sedert die sestiger-, maar veral sedert die sewentigerjare 'n verandering in die Bybelwetenskappe in Suid-Afrika sou intree, en dat die regmatigheid van die 'Skriftuurlike' begronding van apartheid gevolglik onder skoot sou kom, was om 'n verskeidenheid van redes onvermydelik.

Eerstens was dit, afgesien van enkelinge soos J H Kritzinger, E P Groenewald en P F D Weiss, maar eers sedert die vyftigerjare dat dosente van die Ned Geref Kerk in Semitiese Tale en Ou- en Nuwa Testament self in daardie vakke gepromoveer was (Fensham 1969:81-83). Gevolglik was dit maar eers seder die laat vyftigerjare dat studente nagraadse studies onder hierdie persone kon onderneem. Fensham (1969:83), wat self promotor was vir ses en twintig doktorskandidate, het gelyk wanneer hy sê: 'Met die vermeerdering in getal promovendi in die Ou Testament en Semitiese tale het 'n gesprek moontlik geword wat bevrugtend inwerk.'

Tweedens dui die stigting van die Ou-Testamentiese (1957) en Nuwe-Testamentiese (1965) Werkgemeenskappe (vgl Van Selms 1959) op 'n groter selfstandigheid in die Bybelwetenskappe in Suid-Afrika. Deur dié organisasies is daar, benewens denominasionele wisselwerking, ook gereelde internasionale kontak. Teen 1969 is kongresse van die OTWSA byvoorbeeld reeds toegespreek deur mense soos Th C Vriezen (Utrecht), G Fohrer (Erlangen), J Bright (Richmond), A Malamat (Jerusalem), J Barr (Manchester) en A S Herbert (Birmingham) (Fensham 1969: 84). Groter teologiese selfstandigheid het ook uitdrukking gevind in: 
* meer teologiese studente wat hulle doktorale studies in Suid-Afrika voltooi het;

* eie Suid-Afrikaanse handboeke vir die Bybelwetenskappe;

- verskeie nuwe Afrikaanse teologiese tydskrifte;

* populêr-teologiese boeke in Afrikaans wat, soos Van Selms (1959) vir die OTWSA se lede in die vooruitsig gestel het, die publiek ingelig het oor ontwikkelings op teologiese gebied.

Derdens is daar sedert die jare sestig in kringe van die Ned Geref Kerk intensief oor ekumene en ekumeniese betrekkings gedebatteer - 'n onderwerp wat in die vorige era vir liberalistiese interkerkisme aangesien is. Hoewel die ekumeniese gesprek nog in dié tyd moeilik sou verloop (De Gruchy 1974) skryf Hanekom (1964:67) dat die 'tydperk van akademiese isolasie, wat in meer as een opsig saamhang met wetenskaplike onvolwassenheid, nou verbygaan', en bepleit hy interdissiplinêre, interkerklike en internasionale samewerking op die gebied van die teologie. Iets hiervan was reeds besig om te gebeur: Al hoe meer nagraadse studente het by teologiese inrigtings anders as die (tradisionele) Vrye Universiteit, byvoorbeeld Kampen of Basel, gaan studeer. Ander het ná-doktorale studies aan universiteite soos dié van Groningen, Leiden, Göttingen, Tübingen, Münster, Bonn, Marburg, Basel, en Londen onderneem. Dit het 'n inligtingsontploffing en perspektiefverskuiwing veroorsaak wat noodwendig die eng horison van die Boere-Calvinisme moes verskuif.

Vierdens het die stigting van interdenominasionele Bybelkundedepartemente 'n verskeidenheid in benadering tot Bybelwetenskappe tot gevolg gehad. In 'n resensie op 'n 1980-simposiumpublikasie merk Jonker (1981:240) onder meer op: 'Heterogene groothede staan hier langs mekaar. Is dit kenmerkend van ons teologiese toekoms?' Dat die teologiese toneel inderdaad gaandeweg heterogeen geword het, is waar; maar dit beteken nie, soos Jonker se stelling mag impliseer, dat standpunt vir altyd teenoor standpunt sou bly staan nie. Soos Heisenberg (1969) tereg aanvoer, verander so 'n situasie mettertyd die menslike bewussyn self.

Vyfdens moes die woelinge in Nederlandse Gereformeerde kringe rondom Skrifbeskouing en Kuyperianisme (Potgieter 1965; Huijser s a; Trimp 1970; Kuiper 1971; Van Genderen 1971) noodwendig die een of ander tyd in die Suid-Afrikaanse gesprek aan die orde kom. Tussen studente van die sestigerjare was onderwerpe soos 'Skrifbeskouing', 'historisiteit', en 'geskiedenis en verkondiging' aan die orde van die dag en in die sewentigerjare het dié debat openlik in kerklike kringe begin (vgl Deist 1976; Vorster 1979).

Sesdens het dit duidelik geword dat die Westerse meganistiese wêreldbeeld (waarteen die gereformeerde teologie tereg so geprotesteer het) intussen verander het (vgl Rund 1961). Venter (1965:231) het dit só opgesom: 'In die eerste plek is 
die [nuwe] wêreldbeeld dinamies, indeterministies. Materialistiese beskouinge is ingeruil vir meer biologiese, psigologiese en sosiologiese beskouinge. Die nadruk val nie meer soseer op waarneming en logiese denke nie, maar op begrippe soos lewe, eksistensie, skepping, ens...Verder, die geheel word vandag meer beklemtoon as die samestellende dele.'

Dié verandering het gemaak dat die ou strydpunte irrelevant begin word en die konteks waarbinne teologie bedryf is, vir' $n$ ander benadering gevra het.

In die sewende plek het daar in die sistematies-teologiese gesprek 'n wending gekom. Waar die kollig vroeër slegs op Gereformeerde denkers of apologeties op skeptici geval het, het die gesprek 'n meer internasionale en interdenominasionele karakter aangeneem (vgl bv Van Huyssteen 1969; Lategan 1970; Du Plessis 1972; Louw 1973; König 1974; Wethmar 1977; Pieterse 1978).

In die agtste plek: Terwyl die apartheidstelsel eers werklik in 1961 met Republiekwording grondwetlik vasgelê is, was 1961 ook die jaar van die waterskeidende Cottesloe-beraad (Lückhoff 1978; vgl Lede van S A Werkgemeenskap vir Sendingwetenskap 1980), waar die tradisionele band tussen apartheidspolitiek en konserwatiewe teologie verbreek is toe konserwatiewe teoloë hulle ook sterk uitgespreek het teen die Ned Geref Kerk se Skriftuurlike begronding van die staat se rassebeleid: 'Die Afrikaanse kerke het...die perke van hulle profetiese getuienis oorskry, toe hulle knaend by die owerheid daarop aangedring het dat laasgenoemde 'n Wet op Gemengde Huwelike sou instel. Vir hierdie profetiese getuienis het hulle geen grond in die Skrif gehad nie? (Verhoef 1961b:168).

In die negende plek het die sendingsituasie teologiese opvattings wat vroeër as vanselfsprekend korrek aangesien is, skerp bevraagteken (vgl Burden 1973; Bosch 1972a). Sendelinge wat ook Bybelwetenskaplikes was, het akuut bewus geword van die irrelevansie van die klassieke Gereformeerde hermeneutiese raamwerk vir Afrika (Pretorius 1980a; 1980b) en aan nuwe, meer kontekstuele interpretasie-raamwerke begin werk (De Villiers 1973:241).

In die tiende plek het die opkoms van swart teologie en bevrydingsteologie die 'slegs blankes'-greep op die (Gereformeerde) teologie in Suid-Afrika gebreek. Ned Geref teoloë moes hulle toenemend verantwoord teenoor 'n interpretasie van die Skrif wat vreemd was aan die tradisionele Gereformeerde opvattings (vgl Bosch 1972b; Boshoff 1973; Crafford 1973; Meiring 1975; Boesak [red] 1976).

In die elfde plek het die geslag teologiese dosente uit die vyftigerjare, wat self reeds onder mekaar verdeeld was oor die legitimiteit van die Boere-Calvinisme, die tuig die een ná die ander in die sewentigerjare neergelê. Hulle plekke is ingeneem deur 'n generasie wie se biografieë en teologiese opleiding (veral sover dit ná-doktorale studie betref) skerp van hulle s'n verskil het. Sommige uit die nuwe geslag sou 
selfs ietwat reaksionêr reageer op die verlede en die Kerk van tyd tot tyd in beroering bring.

In die twaalfde plek het die snel veranderende politieke situasie self die outoritêre aanslag en sekerhede waarmee die vorige geslag gewerk het, skerp bevraagteken. Sharpeville (1961) en Soweto (1976) en Suid-Afrika se stelselmatige isolasie sou ons situasie permanent verander. Boonop was die woelinge wat die Nasionale Party sedert die laat sestigerjare ondervind het, maar net simptomaties van 'n nuwe geslag kiesers wat nie die sentimente van die strydrosse van die Boere-Calvinisme geken of gedeel het nie en slegs die isolerende effek daarvan beleef het. Die meeste van daardie kiesers was ook kerkmense.

Die (onbewuste) koloniale perspektief waarmee Boere-Calviniste die empiriese ('natuurlike') gegewens op 'n naïef-realistiese manier vir hulle kultuurbeskouing gehaal het, was polities aan die verbrokkel en die fundamentalistiese hermeneutiek waarmee apartheid Skriftuurlik begrond is, is deur die wyer teologiese en wysgerige blootstelling ondergrawe. Die klok het dus reeds in die vroeë sewentigerjare gelui vir die sosiaal-politiese, kenteoretiese èn hermeneutiese basis van Boere-Calvinisme vir wie apartheid 'n vanselfsprekende kultuurbeginsel was. Dit is daarom nie vreemd dat die sinodale dokument Ras, volk en nasie in die lig van die Skrif die lig juis in 1974 gesien het nie.

\section{DIE ALTERNATIEWE VERSKEIDENHEID}

Byna 40 jaar gelede het Van Schalkwyk (1952:134-135) die volgende te sè gehad oor die aanvaarding en verwerping van teorieë:

Die kulturele milieu waarin mense hulle bevind, is 'n belangrike determinerende faktor in die aanvaarding of verwerping van teorieë. Dit wat 'n regverdiging bied vir die status quo, of wat die voortbestaan van geaksepteerde waardes waarborg, word aanvanklik aanvaar en by die lewensbeskouing geïnkorporeer. Derhalwe moet altyd met groot versigtigheid gewaak word teen 'n te maklike aanvaarding van stellinge wat in ooreenstemming is met die waardering vir eie kultuurgoedere, of wat 'n subjektiewe waarderingsoordeel regverdig, of wat die voortbestaan van eie kultuurvorme waarborg...Onder die huidige omstandighede is ons in Suid-Afrika sterk voorstanders van 'n beleid van apartheid...Ons apartheid het nou deel geword van ons lewensbeskouing. Om so 'n beskouing wetenskaplik te regverdig, want daaraan het ons behoefte, soek ons nou na 'n wetenskaplike basis vir ons argumente ten gunste van 'n apartheidsbeleid...Is dit nie moontlik dat 'n vol- 
gende geslag, wat miskien nie dieselfde maatstawwe sal toepas om waardes te meet nie, heeltemal ander beskouinge sal hê nie? Dan sal hulle weer teenargumente ophoop om te bewys hoe onwetenskaplik hierdie geslag te werk gegaan het...Myns insiens is die mees wetenskaplike benadering dié waar ons begin deur by ons self navraag te doen na ons eie subjektiewe waarderingsoordele. Die wetenskaplike moet helder bewus wees van sy eie vooroordele, die maatstawwe wat hy toepas in die lewe, en watter eie kultuurgoedere vir hom 'n waarde het. Dan het hy min of meer ' $n$ idee van die selfverdedigingsmeganisme in sy denke waarmee hy rekening moet hou. Dan weet hy ten minste waar die terreine is waarop hy met groot versigtigheid en selfkritiek moet beweeg. Na my mening kan ons skaars meer wees as wetenskaplik-versigtig.

Die debat in Bybelwetenskaplike geledere het die afgelope twee dekades juis gewentel om die rol van selfverdedigende vooronderstellings by Skrifinterpretasie. Dié diskussie het veral vier stelle vrae na vore gebring:

- die vraag na die aard van Bybelse geskrifte;

- die vraag na 'n geskikte metode om Bybelse geskrifte te interpreteer;

- die vraag na 'n geskikte hermeneutiese raamwerk vir Skrifuitleg;

- die vraag na die implisiete kenteoretiese en wetenskapsteoretiese modelle wat deur Skrifuitleggers gebruik word.

Waar vroeë geslagte die Bybel op basis van 'n fundamentalistiese Skrifbeskouing gesien het as 'n boek met eksakte volkekundige, natuurkundige, historiese en teologiese informasie, word dit vandag wyd onder Bybelkundiges aanvaar dat die Bybel (religieuse) literatuur is wat onvermydelik deel het aan die kulturele oortuigings van destyds en waarin die skrywers die werklikheid waaroor hulle vertel, noodwendig vanuit spesifieke perspektiewe geteken het (Vorster 1972, 1979, 1980; Deist 1973; Du Rand 1983). Dit beteken dat Bybelinterpretasie nie 'n esoteriese metode benodig nie, maar gedoen moet word met die apparatuur wat vir enige ander (antieke) literère dokument geld.

Vanaf die vroeë sewentigerjare vind 'n mens daarom by Bybelkundiges ' $n$ buitengewone belangstelling in taal- en literatuurwetenskap. Vandag is daar' $n$ verskeidenheid van eksegetiese metodes in gebruik, waarvan die oorwig aan die een of ander literère teorie ontleen is. Skrifuitleg het die pad tussen strukturalisme (Du Toit 1974, 1980; Lategan 1978; Combrinck 1983), sosiologiese teksanalise (Deist 1983; Le Roux 1987b) resepsieteorie (Lategan 1987; Combrink 1988b) en dekonstruksie tree vir tree saamgestap. 
Nie alle pogings was ewe suksesvol nie en hier en daar het ons as teoloë in die Ned Geref Kerk heeltemal te gou en uit ons beurt gepraat, maar twee dinge het ons gewen. Eerstens is die literalistiese opvatting van die Bybel as direkte Godswoord, wat God as 't ware tussen die buiteblaaie van die Bybel 'beskikbaar' gemaak het, vervang met die insig dat ons in die Bybel nie te make het met letterlike Godsuitsprake nie, maar met menslike taal wat beeldend en metafories heenwys na 'n ander dimensie (Van Huyssteen 1973, 1988b), en dat dit juis die metaforiese meerduidigheid van die Bybel is wat ruimte gee aan die Gees om te waai waar Hy wil.

Tweedens is die opvatting dat geïsoleerde verse individuele Godsprake is wat nog net deur die dogmatiese raamwerk van die eksegeet gesistematiseer moet word, en wat dekades lank vers en kapittel 'teologiese' dekking verleen het aan ideologiese standpunte, verruil vir die insig dat die primêre betekenis van 'n teksgedeelte uit die tekstuele konteks afgelei moet word, en nie primêr uit die leser se verwysingsraamwerk nie (vgl Deist 1987a, 1987b).

Die vraag oor wat 'tekstuele konteks' regtig beteken, is nog steeds in debat. Sommige meen dit gaan slegs oor teksverband binne dieselfde teks en gebruik die een of ander strukturele of strukturalistiese interpretasie-apparaat. Ander reken 'literêre konteks' sluit die lesers wat die Bybel deur die eeue gehad het in, en maak van teksresepsie-teorieë gebruik. Ander verstaan 'konteks' as die sosiale, ekonomiese en politieke strukture waarbinne die teks ontstaan en voortgeleef het en maak van die een of ander ideologie-kritiese interpretasie-model gebruik. Nog ander neem 'konteks' as intertekstualiteit op en werk in die rigting van dekonstruksie. Daar is geen sprake meer van 'n monolitiese interpretasie-kanon nie.

Bybelinterpretasie het weer interessant geword omdat die eksegeet nie by voorbaat weet wat daar staan nie, en dus telkens gefrustreer of verras kan word.

'n Teoloog sonder ' $n$ teologiese raamwerk is egter, met apologie aan Botha (1978:1), soos 'n spook sonder 'n laken. Wat uit die Bybel verstaan word, moet nog êrens (dialogies) in 'n teologiese raamwerk geplaas word om teologiese sin te maak. Toe die greep van die ortodokse raamwerk in die sestigerjare afgeskud is, het sommige Bybelwetenskaplikes met ' $n$ redelik siniese en relatiwistiese raamwerk geopereer. Dit was 'n natuurlike reaksie op die sekerhede van hulle naief-realistiese en positiwistiese opleiding.

Die sewentigerjare is gevolglik gekenmerk deur skerp debatte tussen Bybelwetenskaplikes en deur 'n verskeidenheid van standpunte oor die Bybel en Bybeluitleg (vgl Deist 1978; Lategan 1978; Combrink 1988a). 'n Enkelvoudige alternatief op die ortodokse teologiese raamwerk is nog steeds nie in sig nie, hoewel die felheid van die debat van die sewentigerjare in die tagtigerjare plek gemaak het vir ' $n$ veel groter toleransie. 
Die rede vir die toleransie lê in die ontwikkeling van 'n kenteoretiese en metodologiese bewussyn by Bybeluiteggers, waaroor 'n paar opmerkings ter sake is.

Nietzsche het gesê: As jy 'n duiwel 'n naam gegee het, het jy hom besweer. Die weerstand wat Bybelkundiges van die sewentigerjare teen die klassieke model ervaar het, is miskien juis gevoed deur die feit dat hulle nie die vinger op die verskilpunte kon lê nie. Dit was met hulle soos met Job en sy vriende, wat ernstig van mening verskil het en mekaar nie kon vind nie, omdat hulle met dieselfde basiese argumentstruktuur gewerk het. Die dooiepunt sou eers heelwat later deurbreek word toe Bybelkundiges, min of meer vanaf die middel sewentigerjare, met erns begin aandag gee het aan kenteoretiese kwessies wat by teologiese kennis (Van Huyssteen 1969, 1975, 1983, 1986, 1988a, 1988b) in die algemeen en by Bybeluitleg in die besonder (Deist 1979/80, 1979, 1983, 1988) in die spel gekom het. Dit was in dié tyd dat die insig gedaag het dat die probleem met die ortodokse teologiese raamwerk nie soseer in Gereformeerdheid as sodanig gesetel het nie, maar in die naïefrealistiese kenteorie ten grondslag van Boere-Calvinisme. Dié insig, tesame met die insig dat 'n eksegeet se sosio-politieke konteks inderdaad deel van die Bybel se 'interteks' is, het begrip gekweek vir die ortodokse generasie en het 'n gesprek moontlik gemaak.

Die nuwe geslag het, in lyn met die gees en behoeftes van die tyd, gekies om met een of ander vorm van 'n krities-rasionalistiese of krities-realistiese kenteorie te werk en met 'n hipoteties-deduktiewe metodologie. Teologie het, soos enige ander wetenskap, 'n hipotetiese wetenskap geword met veel minder sekerhede, maar hopelik met 'n veel groter probleembewussyn. Dit was net nie meer moontlik om politieke en ekonomiese strukture Bybels te onderbou en ideologiese status te verleen nie. Teologie is nou eerder 'n maatskappy-kritiese as 'n maatskappy-funderende bedryf, soos dit ook gebeur het in die kritiek op apartheid.

\section{DIE UITWERKING VAN DIE NUWE INSIGTE OP DIE BESKOUING OOR DIE BYBEL}

Die wending in die kenteoretiese en wetenskapsfilosofiese vertrekpunte het ook die Bybelse dokumente self in 'n heel nuwe lig gestel. Die Bybel was nou nie meer 'n monolitiese blok Godsprake wat bloot net (Gereformeerd) gesistematiseer moes word nie. $\mathrm{Na}$ analogie van die insig dat kennis in hoë mate sosiaal bepaald is, het die insig gedaag dat Bybelse tekste, of dit nou poësie of filosofie of verhale of briewe is, ook uit bepaalde sosiale beddings ontspring het, en dat dit as sodanig verstaan moet word. Dit het duidelik geword dat die Bybel nie 'n enkele antwoord verstrek op sosiaal-ekonomiese vraagstukke nie, maar met verskeie voorstelle na vore kom. Sommige tekste, soos dié waarop die apartheidsteoloë hulle beroep het, weerspieël 
byvoorbeeld 'n sterk eksklusiwistiese tendens, terwyl ander 'n sterk inklusiwistiese tendens het. Soms kom beide standpunte binne dieselfde stuk literatuur voor. Sommige tekste is sterk pro-monargie; ander is anti-monargaal. Sommige beskou rykdom en besittings as 'n seën van God en armoede as die produk van domheid of luiheid, terwyl ander tekste rykdom as ydelheid en armoede as 'n deug beskou.

Dit is net nie meer moontlik om die Bybel vir dié of daardie politieke of ekonomiese 'saak' te monster nie, omdat die Bybel nie 'n eenvormige verhaal oor sosiopolitieke aangeleenthede te vertel het nie. Die verskeidenheid in die Bybel voorsien weliswaar die teoloog met ' $\mathrm{n}$ arsenaal van moontlikhede, maar dit gee hom of haar nie 'n enkelvoudige antwoord nie. Die verskeidenheid in die Bybel dryf die teoloog daarom telkens terug na die debat, na herbesinning, na nuwe oorweging.

Teologie is nie meer die argief van sekerhede nie, omdat God nie meer in die Bybel 'beskikbaar' is nie. Teologie moes van voor af leer dat die waarheid oor God en sy wil gesoek moet word, met name in gemeenskap met gelowiges van uiteenlopende opinies. Die era van contra principia negantem, non est disputandum is vir goed verby, omdat ons juis die alternatief op ons opinie nodig het as ons nader aan die waarheid wil kom.

Hierdie veranderings het vanselfsprekend 'n effek gehad op Bybelkundiges se beskouing oor die Skrif as openbaring van God. In diê verband het een van die basiese metafore van die Christelike geloof weer in sy volle dialektiek voor ons te staan gekom, naamlik die metafoor van die inkarnasie: om Homself te openbaar, het God Hom in die mens Jesus van Nasaret verberg. Hieroor 'n paar slotopmerkings.

In Jesus van Nasaret, so glo die Christendom, het God só eg deel van die menslike geskiedenis geword dat die blote oog Hom nie kon herken nie. Dit was juis omdat die kerklui God so anders voorgestel het dat hulle Hom nie in Jesus herken het nie en Hom gekruisig het. Maar dit is ook juis in sy incognito dat God geillustreer het hoe Hy verkies om Homself bekend te maak: nie in die dwingende bewys van die logika, die oormag van geweld of deur esoteriese Delfiese orakels nie, maar in die magtelose gedaante van 'n mens en deur alledaagse, soms kontradiktoriese, gebeurtenisse en beskouings. God is geen dwingeland nie. Hy kom tussen ons en in ons geskiedenis in en stel ons voor die geloofskeuse om Hom te herken of te kruisig.

As dit is hoe God Homself bekend maak, volg twee dinge hieruit: eerstens dat ons in ons sekerheid oor wie en wat God is, Hom selfs Bybel-in-die-hand en skrifgeleerd soos ons is, maklik in die geskiedenis kan miskyk en kruisig; tweedens, as God Homself dan in die alledaagse vloei van die geskiedenis bekend maak, kan ons begrip van God nie deur historiese veranderinge onaangeraak bly nie, net soos die geskiedenis-skoppelmaai in Bybelse tyd die Godsbegrip nie onaangeraak gelaat het nie. In elke nuwe omstandigheid is ' $n$ ander faset van die Godheid openbaar 
gemaak. Uit die slawekerkers van Egipte lyk die gesig van God anders as vanaf die goue troon van Salomo in Jerusalem, en vanaf die ivoorbeddens in Samaria anders as uit die kleinboerkrotte op die platteland van Efraim. Maar in die kontradiksies tussen slawekerkers en goue trone, ivoorbeddens en kleinboerkrotte, en in die alledaagse van stene te maak in Egipte en 'n land uit Jerusalem te administreer, van geld te maak in Samaria en in Efraim te wag vir die reën om te kom, is God besig om Homself bekend te maak. In die kontradiksie tussen vertroostende priester en vermanende profeet neem God se gesig gestalte aan.

Wie God slegs in die goue troon van Salomo raaksien, sal saam met Israel hulle liere aan die wilgerbome ophang en klaagliedere sing as die gety draai. Wie God slegs met die kerkers van Egipte identifiseer, sal Hom, soos Israel, verloor as die dag van voorspoed kom en Hom eers weer ontdek as die koning in boeie is, die tempel verbrand, die profete dood en die priesters verban is.

God maak Homself in die kontradiksies van die geskiedenis bekend. Maar $\mathrm{Hy}$ het ons nie onkundig gelaat oor sy manier van doen nie. Die Bybel vertel die verhaal van God se selfbekendmaking in die historiese kontradiksies van slawerny en vryheid, armoede en rykdom, die vestiging en ondergang van politieke koninkryke en ideologieë. En die Bybel waarsku ons dat God se incognito slegs deur die oog van die geloof ont-dek kan word. Wie dié gawe weier, hang die Seun van God aan 'n kruis op in die waan dat hulle aan God'n diens bewys.

Sekerhede oor wat ons in ons eie tyd van God moet dink, het ons nie. Ons het slegs die kontradiksies van ons geskiedenis, die Bybelse roetekaart en...mekaar. Waarvan die Bybel ons verseker, is dat God tussen ons teenwoordig is en dat ons die getuienis van ryk èn arm, slaaf èn vryman, man èn vrou, Jood en Griek nodig het as ons Hom in hierdie maalstroom wil herken.

\section{Literatuurverwysings}

Boesak, A A (red) [1976]. Om het zwart te zeggen: Een bundel opstellen over centrale thema's in de zwarte theologie. Kampen: Kok.

Bosch, D J 1972a. Inheemswording, Afrikanisering en swart teologie. NGTT 13/2, 103-115.

-- 1972b. Geestelike opbou en ekumeniese betrekkinge by die Ned Geref Dogterkerke. NGTT 13/3, 129-139.

Boshoff, C H W 1973. Die swart teologie as bevrydingsbeweging. NGTT 14/1, 5-20. Bosman, H L 1987. Wetenskapsteorie en inleidingswetenskap. Skrif en Kerk 5, 5359.

Botha, R P 1978. Voorwoord tot Sinclair, M. Chomsky se teorie van kerngrammatika. Pretoria: Universiteit van Pretoria. 
Burden, J J 1973. Soeklig op kategese in die NG Kerk in Afrika. NGTT 14/1, 48-65.

Combrink, H J B 1983. Die pendulum swaai terug - enkele opmerkings oor metodes van Skrifinterpretasie. Skrif en Kerk 4/2, 3-15.

--- 1986. The changing scene of biblical interpretation, in Petzer, J H \& Hartin, P J (eds) 1986, A South African perspective on the New Testament: Essays by South African New Testament scholars presented to Bruce Manning Metzger during his visit to South Africa in 1985, 9-17. Leiden: Brill.

-- 1988a. Strukturalisme, is 'n herwaardering nodig? NGTT 29/2, 129-138.

-- 1988b. Readings, readers and authors: An orientation. Neotestamentica 22, 189 203.

Crafford, D 1973. Swart teologie en die NG Kerk in Afrika. NGTT 14/1, 36-47.

De Gruchy, J W 1974. Reflections on dialogue between the Afrikaans and Englishspeaking churches. NGTT 15/2, 120-128.

Deist, F E 1973. Ou-Testamentiese eksegese en algemene literatuurwetenskap. NGTT 14/1, 75-81.

-- 1976. Historiese heuristiek, teologiese hermeneutiek en Skrifgesag. Port Elizabeth: UPE.

-- 1979. Gedagtes oor die aard en moraliteit van wetenskaplike kennis. Theologia Evangelica $12 / 2-3,16-21$.

-- 1979/1980. Idealistic Theologiegeschichte, ideology critique and the dating of oracles of salvation. OTWSA 22/23, 53-78.

--- 1983. Bibelinterpretation und/als Ideologiekritik. Old Testament Essays 1, 26-48.

-- 1986. Johannes du Plessis en die Belydenisskrifte. Theologia Evangelica 19/1, 36-65.

-- 1987a. Relatiwisme en absolutisme: Kan dit oorkom word? Oor 'Bybelse' en 'dogmatiese' teologie, in Prinsloo \& Vosloo 1987:1-17.

--- 1987b. 'Gekontroleerde' eksegese en/of 'kreatiewe' uitleg. HTS 44/1, 39-54.

-- 1988. Naïewe realisme en Ou-Testamentiese wetenskap in die Nederduitse Gereformeerde Kerk, in Prinsloo \& Vosloo 1988:23-32.

-- 1990. Notes on the context and hermeneutic of Afrikaner civil religion in Kritzinger, J N J \& Saayman, W A 1990, Mission in creative tension: A dialogue with David Bosch. Pretoria: S A Missiological Society.

De Villiers, D R 1973. Gedagtes oor teologiese opleiding vandag. NGTT 14/4, 238-248.

Du Plessis, I J 1972. Wolfhart Pannenberg en die opstanding. NGTT 13/2, 93-103.

-.- 1976. Op soek na 'n geldige metode van Skrifondersoek. NGTT 17/2, 76-86. 
Du Rand, J A 1983. Die evangelie van Johannes as getuigende vertelling. NGTT 24/4, 383-397.

Du Toit, A B 1974. The significance of discourse analysis for New Testament interpretation and translation. Neotestamentica 8, 54-79.

... 1981. Strukturale teksanalise en die Suid-Afrikaanse redevoeringsanalise - enkele opmerkings aan die hand van Van Iersel se analise van die Emmaus-verhaal. Skrif en Kerk 2, 3-14.

Durand, J J F 1961. Cottesloe, Wêreldraad van Kerke en ekumeniese sending. NGTT 2/3, 147-153.

Erasmus, D F 1946. Ons eie Calvinisme. Die Gereformeerde Vaandel 14/11, 11-12.

Fensham, F C 1969. Ou-Testamentiese en Semitiese studies in Suid-Afrika. NGTT $10 / 2,77-85$.

Groenewald, E P 1952. Die stand van die teologiese wetenskap in Suid-Afrika. Die Kerkbode 1952-03-12, 506-509, 513.

--- 1961. Die Transvaalse Kerk en die Cottesloe-beraad. NGTT 2/3, 131-142.

Hanekom, T N 1964. Academia oecomenica. NGTT 5/2, 65-68.

Heisenberg, W 1969. Der Teil und das Ganze: Gespräche im Umkreis der Atomphysik. Frankfurt: Piper.

Huijser, I P J s a. Het venwordingsproces in de Gereformeerde Kerken. sl: Buijten \& Schipperheijn.

Jonker, W D 1981. Resensie op Vorster (ed) 1980. NGTT 22/3, 239-240.

Kock, P de B 1936. Calvinisme en etiek. Die Gereformeerde Vaandel 4/3, 84-88.

König, A 1974. Pannenberg en Jüngel - huidige tendense in die Godsleer. NGTT $15 / 2,105-119$.

Kotzé, C R [ca 1933]. Die dwaling in ons Kerk. Bloemfontein: Nasionale Pers.

Kuiper, M 1971. Nuwere ontwikkelinge in die Gereformeerde Kerk in Nederland. NGTT 12/1, 60-69.

Lategan, B C 1970. Voorlopers van die 'Nuwe Hermeneutiek'. NGTT 11/1, 22-28.

--- 1978. Directions in contemporary exegesis: Between history and structuralism. JTSA 25, 18-30.

.-. 1987. Inleidende opmerkings oor resepsieteorie en die uitleg van Bybelse materiaal. NGTT 28/2, 112-117.

Lategan, D 1941. Die bestaansreg en karakter van die Ned Ger Kerk gesien in die lig van die kerklike pluriformiteit. Die Geréformeerde Vaundel 9/10, 304-307.

.-. 1944. Die Gees van Elia. Die Gereformeerde Vaandel 12/3, 10-14.

Le Roux, J H 1987a. Die verhouding tussen Ou Testament teologie en die geskiedenis van Israel, in Prinsloo \& Vosloo 1987:67-74. 
Le Roux, J H 1987b. As die profeet se woord teleurstel - oor ballingskap, na-ballingskap en na-apartheid. NGTT 28/4, 216-230.

Lede van die S A Werkgemeenskap vir Sendingwetenskap (Transkei-streek) 1980:

Verantwoording van eietydse temas: Die Christen se getuienis in die samelewing - met die Koinonia-verklaring as vertrekpunt. NGTT 21/3, 274-280.

Loots, P J 1957. Brief aan die Redakteur. Die Kerkbode 1957-09-18, 527.

Louw, D J 1973. Die teologie van Jürgen Moltmann: Eschatologia crucis. NGTT 14/2, 107-113.

Louw, J P 1970. Linguistics and hermeneutics. Neotestamentica 4, 8-18.

Lückhoff, A 1978. Cottesloe. Kaapstad: Tafelberg.

Meiring, P G J 1975. Stemme uit die swart kerk. Kaapstad: Tafelberg.

-- 1976. Die agtergrond van swart teologie in Afrika en Suid-Afrika. NGTT 17/2, 87-97.

Moller, H F 1935. Brief aan die Redakteur. Die Kerkbode 1935-12-18, 1241.

Oosthuizen, M J 1989. The God of the exodus: A study of characterisation in Exodus 1-12. DTh-proefskrif, Universiteit van Suid-Afrika.

Pieterse, H J C 1978. Enkele gedagtes oor die implikasies van G Ebeling se hermeneutiek vir die homilitiek. NGTT 19/4, 272-287.

Potgieter, F J M 1958. Veelvormige ontwikkeling: die wil van God. Bloemfontein: SACUM.

--- 1959. Die Institusie van Calvyn. Die Kerkbode 1959-07-08, 13-15.

-- 1959. Akademiese vryheid - 'n waardebepaling. NGTT 1/1, 1-62.

--- 1965. Grondverskuiwings. NGTT 6/3, 129-130.

Pretorius, H L 1977. Wit/swart-bevrydingsteologie in Suid-Afrika. NGTT 18/4, 343-352.

--- 1980a. Die wit dosent voor 'n swart klas - 'n agtergrondsverkenning (1). NGTT 21/3, 253-266.

--- 1980b. Die wit dosent voor 'n swart klas - Analise van 'n model (2). NGTT 21/4, 313-328.

Prinsloo, W S \& Vosloo, W (reds) 1987. Ou Testament teologie: Gister, vandag en môre. (UPTS.) Pretoria: NG Kerkboekhandel.

--- (reds) 1988. in mensetaal oor God se Woord. Huldigingsbudel opgedra aan professor A H Van Zyl. Kaapstad: Lux Verbi.

Redaksioneel 1948. Ons verhouding tot die sektes. Die Kerkbode 1948-02-25, 392 393.

Rund, H 1962. The world-view of modern theoretical physics. Pretoria: Universiteit van Suid-Afrika. 
Strauss, H J 1947. Die Calvinisme en ons blankheid. Die Gereformeerde Vaandel $15 / 2,7$.

Trimp, C 1970. Betwist Schriftgezag. Groningen: Vuurbraak.

'Uit die Vrystaat' 1948. Christelike onverdraagsaamheid. Die Kerkbode 1948-01-14, 60-62.

Van Genderen, J 1971. De reformatorische belijdenis in discussie. 's-Gravenhage: Wellem de Zwijgerstichting.

Van Heerden, S W 1988. Die interpretasie van die boek Jona in die Nederduitse Gereformeerde Kerk. 'n Hermeneutiese studie. DTh-proefskrif, Universiteit van Suid-Afrika.

Van Huyssteen, J W V 1969. Die geskiedenis-teologie van Wolfhart Pannenberg. NGTT 10/4, 200-216.

-.- 1971. Teologie van die rede. Die funksie van die rasionele in die denke van Wolfhan Pannenberg. Kampen: Kok.

--- 1973. God en werklikheid. NGTT 14/2, 132-149.

--- 1975. Bybelkunde, teologie en die Bybel. NGTT 16/2, 139-152.

--- 1981. Die sistematiese teoloog en persoonlike geloofsbetrokkenheid. NGTT 22/4, 291-302.

--- 1983. Thomas S Kuhn en die vraag na die herkoms van ons teologiese denkmodelle. NGTT 24/3, 296-311.

--- 1986. Teologie as kritiese geloofsverantwoording. Pretoria: RGN.

-.- 1988a. Evolution, knowledge and faith: Gerd Theissen and the credibility of theology. HTS 44/1, 16-22.

... 1988b. Beyond dogmatism: rationality in theology and science. HTS $44 / 4,847$. 863.

Van Huyssteen, J W V \& Du Toit, B 1982. Geloof en Skrifgesag. Pretoria: NG Kerkboekhandel.

Van Schalkwyk, A 1952. Wêreldbeskouing en kulturele omgewing. Die Gereformeerde Vaandel 20, 127-135.

Van Selms, A 1959. Die stand van die Ou-Testamentiese wetenskap, insonderheid in Suid-Afrika. HTS 14/2-3, 41-52.

Van Wyk, J A 1976. Latente motiewe in die verklaring van die NG Kerk oor: Ras, volk en nasie en volkereverhoudinge in die lig van die Skrif. NGTT 17/2, 98109.

Van Zyl, A H 1973. Redaksiegeskiedenis en die prediking. NGTT 14/2, 114-125.

... 1979. Geskiedenis en openbaring, in Odendaal, D H, Müller, B \& Combrink, H J B 1979:39-50. 
Venter, E A 1965. Oor die hedendaagse wetenskapsbeskouings. NGTT 6/4, 230232.

Verhoef, P A 1961. Matrimonium mixtum. NGTT 2/3, 153-169.

Vorster, J D 1936. Brief aan die Redakteur. Die Kerkbode 1936-01-22, 186.

Vorster, W S 1972. The gospel of John as language. Neotestamentica 6, 19-27.

... 1974. Concerning semantics, grammatical analysis and Bible translation. Neotestamentica 8, 21-42.

--- 1977. Some remarks on contemporary New Testament scholarship - methodology and the study of the New Testament. Theologia Evangelica 10/2, 27-40.

--- 1979. 'Moderne eksegese' van die Nuwe Testament - 'n ondermyning van Skrifgesag? HTS 35/1, 119-130.

-.- 1980. Tekssoort evangelie en verwysing. Theologia Evangelica 15, 27-48.

-- 1984. The use of Scripture in the NG Kerk: A shift of paradigm or of values?, in Hofmeyr, J W \& Vorster, W S (ed) 1984, New faces of Africa: Essays in honour of Ben (Barend Jacobus) Marais. Pretoria: Universiteit van Suid-Afrika.

--- 1987. Op weg na 'n post-kritiese Nuwe-Testamentiese wetenskap. HTS 43/3, 374-394.

Wethmar, C J 1977. Dogma en verstaanshorison. Amsterdam: Rodopi.

--- 1981. Dogma, kerugma en geskiedenis. Enkele voorlopige gesigspunte in verband met hulle onderlinge verhoudinge. Skrif en Kerk 2/2, 51-63. 